\title{
Needs of Family Members of Patients Admitted to a University Hospital Critical Care Unit, Izmir Turkey: Comparison of Nurse and Family Perceptions
}

\author{
Sibel Büyükçoban ${ }^{\text {Corresp., } 1}{ }^{1}$, Zehra Mermi Bal ${ }^{2}$, Ozlem Oner ${ }^{1}$, Necmiye Kilicaslan ${ }^{1}$, Necati Gökmen ${ }^{1}$, Meltem \\ Ciçeklioğlu ${ }^{3}$ \\ ${ }^{1}$ Anesthesiology and Reanimation, Dokuz Eylül University, Izmir, Turkey, Turkey \\ 2 Intensive Care Unit, Düzce state hospital, Düzce, Turkey, Turkey \\ 3 Public Health, Ege University, Izmir, Turkey, Turkey \\ Corresponding Author: Sibel Büyükçoban \\ Email address: sibel.buyukcoban@deu.edu.tr
}

Purpose: This study aims to compare the perceptions of nurses and families on the needs of the relatives of the patients in Intensive Care Unit (ICU).

Methods: This cross-sectional study was conducted in the ICU of a university hospital. The study comprised 213 critical care patients' relatives and 54 nurses working in the same ICU. Data were collected using the Turkish version of Critical Care Family Needs Inventory (CCFNI) and a questionnaire on the characteristics of the participants. The difference between the perceptions of families and nurses was analyzed using Student t-test. Results: CCFNI's assurance/proximity subscale mean scores ranked first among both patients and nurses. The item "To be assured the best care possible is being given to the patient" was the top priority for both groups. Mean assurance/proximity and information dimensions of relatives were significantly higher compared to nurses $(p<0.001)$. No significant difference was found between the perception of patient relatives and nurses related to support and comfort dimensions $(p>0.05)$.

Conclusion: Patient' relatives needs are underestimated by nurses. This inhibited the performance of ICU nurses in line with the holistic care approach. Educational objectives that include the needs of ICU patients' relatives should be incorporated into the undergraduate and in-service training of nurses. Policies should be established to create space and time for effective relative-nurse communication. 
1 Title Page

2

3 The title

4 Needs of Family Members of Patients Admitted to a University Hospital Critical Care Unit, Izmir Turkey:

5 Comparison of Nurse and Family Perceptions

7 Authors

8

Sibel Büyükçoban, MD. Anestesiologist, Dokuz Eylül University Faculty of Medicine

Department of Anesthesiology, Izmir, Turkey. ORCID: 0000-0002-5756-980X

sibel.buyukcoban@deu.edu.tr

Zehra Mermi Bal, MD. Anesthesiologist, Düzce Atatürk State Hospital Intensive Care Unit,

Düzce, Turkey

ORCID:0000-0003-3691-7067

zehramermi@gmail.com

Özlem Öner, MD. Anesthesiologist, Dokuz Eylül University Faculty of Medicine Department of

Anesthesiology and Reanimation, Subdivision of Critical Care Medicine, Izmir, Turkey

ORCID:0000-0002-986-4118

namdaroner@gmail.com 
31 Necmiye Kılıçarslan, Nurse, Dokuz Eylül University Faculty of Medicine Department of

32

Anesthesiology and Reanimation

ORCID:0000 00019024 492X

necmiye.kilicaslan@deu.edu.tr

Ali Necati Gökmen, MD. Professor, Dokuz Eylül University Faculty of Medicine, Department of

Anesthesiology and Reanimation Subdivision of Critical Care Medicine, Izmir, Turkey

ORCID:0000-0002-3225-7666

necatigokmen@yahoo.com

46

Meltem Çiçeklioğlu MD. Professor, Ege University Faculty of Medicine, Department of Public

48

Health, İzmir, Turkey ORCiD:0000-0002-7059-7573

50

meltem.cicekli@gmail.com

52

Corresponding author

57

58 Sibel Büyükçoban, MD. Anestesiologist, Dokuz Eylül University Faculty of Medicine 
Department of Anesthesiology Izmir Turkey

61 E-mail: sibel.buyukcoban@deu.edu.tr

62

Phone number: +905056443197

64

Fax number: +902324122801

ORCID: 0000-0002-5756-980X

68

Address requests for reprints: Dokuz Eylül University Araştırma ve Uygulama Hastanesi

Funds

No institutional departmental funds were received in the conduct of the study.

Conflict of interest

75

Authors have not disclosed any potential conflicts of interest

Acknowledgement

81

We are grateful to the family members and nurses of the Intensive care unit for their participation and involvement in the study. We are grateful for the support of the following staff: Uğur Koca, Elvan Öçmen, Hale Aksu

85 Erdost. 


\section{Needs of Family Members of Patients Admitted to a University Hospital Critical Care Unit, Izmir Turkey:} Comparison of Nurse and Family Perceptions

\section{Abstract}

Purpose: This study aims to compare the perceptions of nurses and families on the needs of the relatives of the patients in Intensive Care Unit (ICU).

Methods: This cross-sectional study was conducted in the ICU of a university hospital. The study comprised 213 critical care patients' relatives and 54 nurses working in the same ICU.

\section{Data were collected using the Turkish version of Critical Care Family Needs Inventory (CCFNI) and a} questionnaire on the characteristics of the participants. The difference between the perceptions of families and nurses was analyzed using Student t-test.

\section{Results: CCFNI's assurance/proximity subscale mean scores ranked first among both patients} and nurses. The item "To be assured the best care possible is being given to the patient" was the top priority for both groups. Mean assurance/proximity and information dimensions of relatives were significantly higher compared to nurses $(\mathrm{p}<0.001)$. No significant difference was found between the perception of patient relatives and nurses related to support and comfort dimensions $(p>0.05)$.

Conclusion: Patient' relatives needs are underestimated by nurses. This inhibited the performance of ICU nurses in line with the holistic care approach. Educational objectives that include the needs of ICU patients' relatives should be incorporated into the undergraduate and in-service training of nurses. Policies should be established to create space and time for effective relative-nurse communication.

Key Words: Intensive care, Critical Care Family Needs Inventory, Nurse, Family needs, Critical care

\section{INTRODUCTION}

The stress level of the relatives of the patients who are admitted to Intensive Care Unit (ICU) is quite high due to serious and unstable conditions of their patients $(1,2)$. Moreover, as these patients are mostly unable to communicate due to sedation, mechanical ventilation, confusion, and coma, their family members are asked to make treatment decisions on the patient's behalf (3). Procedures such as tracheotomy, operation consent, and transfer to the service can become very serious sources of conflict with the health care professionals at the point where the patient relatives have all decision-making rights. ICU nurses are in close contact with patients and their families, so they can support family members to overcome this process 
123 (2). In general, nursing practice plays a key role in the hospital setting. However, ICUs, where confusion 124 and uncertainty prevail, are quite dynamic environments for nurse. This necessitates taking, fast and correct

125

126

127

128

129

130

131

132

133

134

135

136

137

138

139

140

141

142

143

144

145

146

147

148

149

150

151

152

153

154

155

156

157

158

159

160

161

162

163

decisions. (4). Duties expected from a nurse under intensive care conditions may limit their ability to respond and support the needs of patient families when caring for intensive care patients (5). The negligence contradicts with the holistic care approach, which is one of the professional features of the profession. Family participation, which is at the center of the holistic care approach, is an important component of the patient's treatment process $(3,6)$. Because the family effect is an important component in the patient's response to treatment, and nurses are medical personnel who best meet the emotional and social needs of families having patients treated in intensive care (5). Organizational factors, work environment, nursing culture and the situation of the family affect the provision of family-centered services of nurses (7). Considering that patient-centered care is moving towards family-centered care in the provision of nursing services, it is very important to assess the needs of inpatient families, especially in intensive care units (1).

Family members may experience extreme stress and anxiety, feel helpless and unable to cope with this situation (3). Fear of death of their loved one, uncertainty about prognosis, financial concerns, changes in family roles, limited access to the critical care environment trigger feelings of shock, anger, denial, and despair within 72 hours after admission to the ICU. They may even lead to feelings of guilt and depression in some cases $(8,9)$.

Correct assessment of their needs is one of the first steps in providing appropriate health care to ICU patients and their families. Molter and Leske (1986) first described needs of the families of patients in critical care units under five dimensions; 1) support, 2) comfort, 3) information, 4) proximity, and 5) assurance $(10,11)$. Nurses provide or coordinate requirements such as fulfilling the family's need for in these five dimensions through bedside family/patient interactions. Problems in understanding these family needs may make it difficult to cope with the crisis, which may eventually affect the patient's response to treatment (12).

Examining family members 'and nurses' perceptions of the needs of inpatient families in the ICU can provide an overview of the improvement of practices in this unit. Despite increasing evidence obtained from studies conducted in this area, the number of studies conducted in the Turkish society in the literature is very low $(13,14)$.

The socio-cultural and geographic contexts responsible for the diversity of family needs of ICU patients can be very important factors, so evidence from different cultures of the world is important (15). The objective of this study is to compare the perceptions of nurses and families on the needs of the relatives of the patients in a university hospital Intensive Care Unit (ICU).

\section{METHODS}

\section{Setting and Samples}

The present cross-sectional study was carried out at the Anesthesia Intensive Care Unit of Dokuz Eylül University Medical Faculty Hospital, one of the two major university hospitals in Izmir. The unit has a capacity of 13 beds, average staffing is two patients per nurse and annual patient capacity ranges between 450 and 500. The ICU, which provides tertiary-level intensive care, offers services to postoperative cases as well as patients who require mechanical ventilation for reasons such as polytrauma, chronic obstructive pulmonary disease, sepsis, and head trauma. Three days a week, medical information is given to the

Peer) reviewing PDF | (2020:10:54535:1:1:CHECK 22 Jan 2021) 
164

165

166

167

patient's relatives by a critical care physician. Afterwards, the attending nurse gives a bedside briefing on the day of the visit about the necessary materials and nursing care, and the questions of the patient's relatives are answered.

In this study, the average number of patients per year was accepted as a population size of 500, as only one family member was interviewed for each patient. The sample size representing the population was calculated as 278 using a $95 \%$ confidence interval, a $5 \%$ margin of error and unknown prevalence. A total of 213 family members of patients enrolled in the study, coverage rate was $76.6 \%$. The study targeted all 57 nurses working in the same critical care unit, and $94.7 \%$ ( $n: 54)$ coverage was achieved.

Inclusion criteria for patient families included.

(1) Age of 18 years or older

(2) Being a relative of the patient who signs informed consent form at hospital admission and related by kinship or marital relationship with the patient.

(3) visited the critically ill patient within 24 to 72 hours after admission of the patient over 18 years of age in the ICU. Although the indications for hospitalization are very diverse, all of them are patients who are connected to a mechanical ventilator and whose relatives have been informed that they are in high danger of life.

(4) willing to participate in the study

(5) being able to read and write.

The inclusion criterion for nurses, on the other hand, was to be working in the Department of Anesthesiology and Reanimation Intensive Care Unit for at least six months. All nurses serve in the same working order alternately in 8-and 16-hour shifts.

\section{Data Collection Tools}

The research data were collected using a questionnaire form, where the characteristics nurses and patients were questioned separately, and the Turkish version of Critical Care Family Need Inventory (CCFNI) (16). The questionnaires given to patient families included items questioning the age, gender, diagnosis of the patient as well as the age, gender, and relationship with patient. The questionnaires applied to nurses included the age, the duration of work in the ICU, and the experience of being a relative of a patient previously admitted to a critical care unit. The Critical Care Family Need Inventory adapted to Turkish by Büyükçoban et. al. was used in this study (16). The questionnaire developed by Leske comprised forty-five items that formed five major family "need" dimensions, namely, support (15 items), information (8 items), proximity or closeness ( 9 items), assurance ( 7 items) and comfort (6 items). Participants were asked to indicate the level of importance of each item measured on a 4-point Likert scale as follows; 1) Not important; 2) Slightly important; 3) Important; 4) Very important. Leske reported that the Cronbach alpha internal consistency coefficient calculated for the reliability study ranged between 0.61 and 0.88 for subscales and was 0.92 for the whole inventory (11). Unlike the original CCFNI, the revised Turkish version of the Inventory consists of fewer items (40) and three dimensions rather than five. Dimensions of the Turkish adaptation are described as 'support and comfort' (20 items), 'proximity and assurance' (11 items) 
202

and 'information' (9 items). The Cronbach alpha coefficient calculated for the internal consistency of the Turkish inventory is 0.93 for the whole inventory and between 0.83 and 0.92 for the sub scale (16).

In this study, Cronbach Alpha value of the scale was calculated as 0.89 for patient relatives and 0.95 for nurses.

The process of adapting the scale to Turkish was mainly carried out through relatives of patients, however, expert opinion from six intensive care nurses was received in assessment of the validity of the scope and then the expert panel included two intensive care nurses in addition to relatives of patients (16). In a study that used the Turkish version of CCFNI and included 50 nurses, the Cronbach Alpha value was found to be 0.90 (13). In addition, the Turkish version of CCFNI was applied to 8 intensive care nurses working in the cardiology intensive care unit of the same hospital prior to the study and the Cronbach Alpha value was found 0,96 .

\section{Procedure}

Ethical approval was granted by the Dokuz Eylül University Non-Clinical Studies Ethics Committee, and a research permit was obtained from the Head of the Intensive Care Unit of the Dokuz Eylül University Faculty of Medicine Department of Anesthesiology and Reanimation (IRB number: 2666-GOA. 2016/1210, 05.05.2016). Data were collected between July 2018 and January 2019. Participants were verbally informed by an ICU physician about the objectives of the study and their written consent was obtained making clear that their participation would be on a voluntary basis. Confidentiality was preserved though anonymity of participants by refraining from questioning their names. Questionnaires were distributed to the participants by the same researcher, and they were asked to leave the completed questionnaires in the drop-off boxes placed in the waiting room. The research team explained the objectives of the study to the nurses, who were then given 30-35 minutes to fill in the questionnaires in-hospital during their break time. Eight patient relatives who failed to complete the questionnaires were excluded from the study.

\section{Data Analysis}

Data analysis was performed using SPSS 15.0 statistics package program. Independent t-test was used to evaluate the difference between perceptions of families and nurses. Whether the data indicated a homogeneous distribution checked using the Levene test, and in cases where it was not distributed homogeneously, the equal variations not assumed $p$ value was used. A $p$-value of $<0.05$ was regarded as statistically significant.

\section{RESULTS}

The sociodemographic characteristics of the relatives and nurses are given in table 1. Half of the members of patient families participated in the study were women, three quarters of them are in upper secondary education, six out of ten were children of ICU patients (Table 1). Overall, $6.6 \%$ of the relatives of the patients reported that they were in critical care units before and $45.1 \%$ of the relatives were previously admitted to ICU. When the patient characteristics were examined $60.6 \%$ of patients were male and $61.1 \%$ 
were over 65 years of age. Reasons for hospitalization among critical care patients were chronic obstructive pulmonary disease and post-operative care.

The mean age of the nurses was $31,9 \pm 6,1$ and $\% 81,5$ was female. Nurses with critical care experience of five years or more accounted for $35.2 \%$. While $7.4 \%(n=4)$ of the nurses reported that they were previously admitted to intensive care, $68.5 \%(\mathrm{n}=37)$ stated that at least one of their relatives was in an ICU.

A comparison of the mean item scores of patient families and nurses based on their answers to CFFNI items is shown in Table 2. Patient relatives gave the highest rank scores to items "To be assured the best care possible is being given to the patient," "To be called at home about changes in the patient's condition", and "To be assured it is alright to leave the hospital for a while". The needs ranked in the first and third places by the family members were equally important for the nurses. On the other hand, the mean score of patient relatives for both items were higher than that of nurses at a statistically significant level. The other two items perceived among the most important five needs for patient relatives were "To feel that the hospital personnel care about the patient" and "To know specific facts concerning the patient's progress". As for the nurses' perception of needs of patient relatives, the items ranked among the top five except for the two items cited above were "To have questions answered honestly" (second), "To know exactly what is being done to the patient" (fourth), and "To feel accepted by the hospital personnel" (fifth). Six of the ten most important needs ranked by patient relatives were also perceived among the top ten by nurses. Of the top ten needs perceived by relatives six items were related to assurance/proximity and four to information. Of the top ten needs of family members perceived by nurses seven items were related to assurance/proximity, two to comfort/support and one to information.

All the items in the last 10 among the needs of patient relatives were related to comfort and support subtitles. Also, there was no statistically significant difference between mean scores of family members and nurses in nine of these items.

There were statistically significant differences in 26 items in terms of scores provided by nurses and family members. Among these items, in 24 items that demonstrated significant differences, the mean scores of family members were higher. The mean scores of nurses were found to be higher in "To be alone at any time" and "To be told about chaplain services" items where a significant difference existed between the scores of patient families and nurses (Table 2).

The mean score on assurance/proximity subscale was ranked first by both family members and nurses. No statistical significance existed between family members' and nurses'perception of support/comfort needs. In terms of assurance/proximity and information, family members' mean perceptions of needs and mean total scale scores were found to be significantly higher than those of nurses (Table 3 ).

The experience of nurses when their own relatives have been in ICUs has been evaluated. A statistically significant difference in scale between nurses who had and had no experience of having a relative staying in intensive care was found for only one article. While nurses $(2,51 \pm 0,90)$ who had experience of having a relative staying in intensive care unit gave higher score for "To talk to the same nurse every day" article nurses $(1,94 \pm 0,85)$ having no such experience gave lower score ( $p: 0.035)$.

\section{DISCUSSION}

This study evaluates the degree of coherence between the perceptions of the ICU nurses who assume the most important responsibility for fulfilling the needs of the patients as well as their families in ICU and the 
281

282

283

284

285

286

287

288

289

290

291

292

293

294

295

296

297

298

299

300

301

302

303

304

305

306

307

308

309

310

311

312

313

314

315

316

317

318

319

320

321 needs of patient relatives. It is very important to identify the difference between the perceptions of nurses and the needs of patients' relatives in the provision of family-centered nursing services in intensive care units.

Coherent with the literature, the results of this study showed that there are similarities and differences in terms of family members and nurses' perceived need for patient relatives. $(12,17,18,19)$. Family scores were higher than those of nurses. This result is supported by the literature, which reports that nurses cannot adequately foresee the level of family needs and shows that the total quality of the services provided to family members of critical care patients is an area that should be improved (20).

Assurance and proximity subscales in the CCFNI developed by Leske (11), which reflect the need of the family to be physically and emotionally close to their critically ill family members, and have confidence in the patient's future, were rephrased under a single title as assurance/proximity in the Turkish version of the scale (16). Although the mean assurance/proximity subscale of family members was higher than that of nurses, it was ranked as the most important need in both groups. The compassionate and honest attitude of intensive care nurses can play an important role in meeting family members' e assurance and proximity need (12). Therefore, it is very important that the nurses in our work group be fully aware of the needs of family members in terms of assurance/proximity needs.

In many studies, assurance dimension was perceived as the highest priority need for both groups $(20,21)$. In a literature review study, on the needs of family members, the assurance was found to be the top-ranked need regardless of the geographical region (22). Furthermore, in the same study, the assurance subscale item "To ensure that the patient is being given the best possible care", which is determined as the most important need for North American families, was ranked eleventh in Asian families (22). In our study, this was the item with the highest score both by nurses and family members. This item was ranked among the top five needs by both nurses and family members in comparative studies conducted in the US (18), Belgium (9), Egypt (21), Turkey (13) and Iran (23).

Although the mean score of family members was higher, the second most important need dimension reported by both groups was 'information'. In addition, the most basic needs of patient's relatives, such as knowing what was done to the patient, what kind of treatment was applied and why these treatments were performed and obtaining information about the changes in the patient's condition were not considered as priority by nurses. Moreover, the article titled "To be called at home about changes in the patient's condition" regarding information dimension was in the second and $12^{\text {th }}$ rank for families and nurses, respectively. This finding showed that patients' need for information was not adequately perceived by nurses as described in the literature $(9,24)$. In Turkey, especially information about treatment processes is mostly covered by doctors $(14,25)$, which may have affected the perception of nurses.

Providing adequate information about the patient's condition, treatment and prognosis also fulfills the needs of families to trust the health system as well as healthcare employees (26). To fulfill patient families', need for information, structured in-depth information tours rather than quick bedside conferences should be made, and nurses should be encouraged to get more actively involved in this process. Considering that this information to be provided to family members may be time consuming, there should be a sufficient number of personnel especially during visiting hours (9). In a study conducted in Turkey it is also found that ICU nurses have problems communicating with the patient's family due to excessive workload, role conflict and uncertainty, environmental and institutional barriers (27).

Peer) reviewing PDF | (2020:10:54535:1:1:CHECK 22 Jan 2021) 
322

323

324

325

326

327

328

329

330

331

332

333

334

335

336

337

338

339

340

341

342

343

344

345

346

347

348

349

350

351

352

353

354

355

356

357

358
The "support and comfort" dimension of patient relatives' needs was perceived as the least important factor by both nurses and patients as described in the literature $(22,26,9)$. In the initial days of emotional distress and continuous search for information, it seems logical that comfort factors have a low priority (9).

Considering the fact that the study was performed in single center where the level of education of patient relatives is relatively high, it should be noted that the generalizability of our results to the population in Turkey is limited. However, the present study similar to other studies in different ICUs in Turkey $(13,14)$ in terms of priority needs of the patients. The low number of nurses that participated in the study should be noted as another limitation.

\section{CONCLUSION}

This study revealed that the most fundamental requirement for both patients and families was assurance and proximity in hospital staff. The second most important factor was the need for information that requires personal communication. However, in both dimensions, the fact that nurses' scores were lower than those of patient relatives indicates that nurses perceive the needs of patient relatives less than their actual needs.

Our study results support the evidence that Turkish version of CCFNI is a valid tool that allows evaluation of the family's needs and nurses' perception on these needs (16). However, as highlighted in the literature, considering the nature of the concepts involving these needs, the results need to be expanded and analyzed in depth using qualitative methods. For the nurses to fulfill such needs of the family members, it is quite important to define and assess these needs accurately. Family-centered care in the intensive care unit is defined as the assurance, emotional support, decision-making support provided by the nurse and acceptance of the family contributions to care (7).

In this framework, new strategies such as, flexible visiting hours, improved participation of nurses in 'visiting and "informing" hours and enhancing the quality of information / counseling processes for patient relatives should be addressed. $(9,22)$. However, owing to staff shortages and excessive workloads, it makes it difficult for nurses to assume this role. For this reason, the health system as well as health institutions should create organizational conditions to support nurses (20).

\section{Funds}

No institutional departmental funds were received in the conduct of the study.

\section{Conflict of interest}

Authors have not disclosed any potential conflicts of interest.

\section{Acknowledgement}

We are grateful to the family members and nurses of the Intensive care unit for their participation and involvement in the study. We are grateful for the support of the following staff: Uğur Koca, Elvan Öçmen, Hale Aksu 


\section{REFERENCES}

1.Khoshnodi Z, Masouleh SR, Seyed Fazelpour SF. 2017. The Importance of fulfillment of family needs at critical care units. J Holist Nurs Midwifery 27:67-73 DOI: 10.18869/acadpub.hnmj.27.3.67.

2.Al Ghabeesh SH, Abu-Snieneh H, Abu-Shahror L, Abu-Sneineh FT, Alhawamdeh MAA. 2014. Exploring the self-perceived needs for family members having adult critically ill loved person: Descriptive study. Health 6:3005-3012 DOI: 10.4236/health.2014.621338.

3.Khatri Chhetri I, Thulung B. 2018. Perception of Nurses on Needs of Family Members of Patient Admitted to Critical Care Units of Teaching Hospital, Chitwan Nepal: A Cross-Sectional Institutional Based Study. Nurs Res Pract 2018: 1-7 DOI: 10.1155/2018/1369164.

4.Mendonca D, Warren NA. 1998. Perceived and unmet needs of critical care family members. Crit Care Nurs Q 21:58-67 DOI:10.1097/00002727-199805000-00009.

5. Hetland B, McAndrew NS, Perazzo J, Hickman R. A qualitative study of factors that influence active family involvement with patient care in the ICU: Survey of critical care nurses Intensive Crit Care Nurs. 2018 Feb; 44: 67-75. doi: 10.1016/j.iccn.2017.08.008

6. Al-Mutair AS, Plummer V, O'Brien A, Clerehan B. 2013. Family needs and involvement in the intensive care unit: a literature review. J Clin Nurs 22:1805-1817 DOI: 10.1111/jocn.12065.

7. McAndrew NS. McAndrew N., Schiffman R., Leske J. A Theoretical Lens Through Which to View the Facilitators and Disruptors of Nurse-Promoted Engagement with Families in the ICU. Journal of Family Nursing 2020, Vol. 26(3) 190-212.

8. Azoulay E, Pochard F, Kentish-Barnes N, Chevret S, Aboab J, Adrie C, Annane D, Bleichner G, Bollaert PE, Darmon M, Fassier T, Galliot R, Garrouste-Orgeas M, Goulenok C, Goldgran-Toledano D, Hayon J, Jourdain M, Kaidomar M, Laplace C, Larche'J, Liotier J, Papazian L, Poisson C, Reignier J, Saidi F, Schlemmer B. 2005. Risk of post-traumatic stress symptoms in family members of intensive care unit patients. Am J Respir Crit Care Med 171:987-994 DOI: 10.1164/rccm.200409-12950C.

9. Bijttebier P, Vanoost S, Delva D. Ferdinande P. Frans E.. 2001. Needs of relatives of critical care patients: Perceptions of relatives, physicians and nurses. Intensive Care Med 27:160-165 DOI: 10.1007/s001340000750. 
394 395

396

397

398

399

400

401

402

403

404

405

406

407

408

409

410

411

412

413

414

415

416

417

418

419

420

421

422

423

424

10. Molter N. 1979. Needs of relatives of critically ill patients: A descriptive study. Heart Lung 8:332-339.

11.Leske JS. 1991.Internal psychometric properties of the Critical Care Family Needs Inventory. Heart Lung 20:236-244.

12.Maxwell KE, Stuenkel D, Saylor C.2007. Needs of family members of critically ill patients: A comparison of nurse and family perceptions Heart Lung 36:367 DOI: 10.1016/j.hrtIng.2007.02.005.

13. Elay G, Tanriverdi M, Kadioglu M, Bahar I, Demirkıran O. 2020. The needs of the families whose relatives are being treated in intensive care units and the perspective of health personnel. Ann_Med Res 27:825-829 DOI: 10.5455/annalsmedres.2019.11.690.

14. Ozbayira T, Tasdemir N, Ozsekera E. 2014. Intensive care unit family needs: Nurses' and families' perception. East J Med 19:137-14.

15.Alsharari AF. 2019. The needs of family members of patients admitted to the intensive care unit. Patient Prefer Adherence 13: 465-473 DOI: 10.2147/PPA.S197769.

16. Büyükçoban S, Ciceklioglu M, Demiral Y1lmaz N. Civaner M. 2015. Adaptation of the Critical Care Family Need Inventory to the Turkish population and its psychometric properties. Peer J 3: e1208 DOI:10.7717/peerj.1208.

17.Moggai F, Biagi S, Pompei.2005. The Needs of Relatives of Patients Admitted to Italian critical units: A survey comparing relatives' and nurses' perceptions. The World Crit Care Nurs 4:23-26.

18-Hinkle JL, Fitzpatrick E. 2011. Needs of American relatives of intensive care patients: Perceptions of relatives, physicians and nurses. Intensive Crit Care Nurs 27: 2218-2225 DOI: 10.1016/j.iccn.2011.04.003

19.Alnajjar H, Elarousy W. 2017. Exploring family needs in neonatal and pediatric intensive care units at King Khaled Hospital- Jeddah. Clin Med Invest 2:1-7 DOI:10.15761/CMI.1000145. 
425

426

427

428

429

430

431

432

433

434

435

436

437

438

439

440

441

442

443

444

445

446

447

448

449

450

451

452

453

454

455

456

20. Gundo R, Bodole F, Lengu E, Maluwa A . 2014. Comparison of nurses' and families' perception of family needs in critical care unit at referral hospitals in Malawi. Open J Nurs 4:312-320. DOI:10.4236/ojn.2014.44036

21.Intessar MA.2019. Comparison between nurses' and families' opinion about priorities of immediate patient's family needs. J Nurs Pract 9:113-121 DOI: 10.5430/jnep.v9n1p113.

22.Padilla CF. 2014. Most Important needs of family members of critical patients in light of the Critical Care Family Needs Inventory. Invest Educ Enferm 32:306-316 DOI:10.1590/S0120-53072014000200013

23. Shorofi SA, Jannati Y, Moghaddam HS, Yazdani-Charati . 2016. Psychosocial needs of families of intensive care patients: Perceptions of nurses and families. Niger Med J 57: 10-18. DOI:10.4103/03001652.180557.

24. Al-Mutair AS, Plummer V, Clerehan R, O'Brien A. 2014. Needs and experiences of intensive care patients' families: A Saudi qualitative study. Nurs Crit Care 19:135-44. DOI:10.1111/nicc.12040.

25. Ünver V. 2003. Yoğun bakım ünitesinde hastası olan ailelerin gereksinimlerinin saptanması. Yoğun Bakım Hemşireliği Derneği 7:75-81.

26.Akhlak S, Shdaifat E. 2016. Needs of Families with relative in a critical care unit. Malaysian J

Public Health Med $16: 75-81$.

27. Çınar D, Olgun N, Koyuncu F. 2005. Yoğun Bakım Ünitesi Hemşirelerinin Hasta Yakınlarını Bilgilendirmede Yaşadıkları Deneyimler: Niteliksel Bir Çalışma 10. Dünya Yoğun Bakım Hemşireleri Federasyonu Kongresi ve 6. Ulusal Yoğun Bakim Hemşireleri Kongresi Hemşirelik Sözlü Bildirileri http://www.jcritintensivecare.org/uploads/pdf/pdf_DCY_80.pdf.HS03:46. 
Table $\mathbf{1}$ (on next page)

Table 1

Sociodemographic Characteristics of Patients and Relatives 
1 Table 1: Sociodemographic Characteristics of Patients and Relatives

2

\begin{tabular}{|c|c|}
\hline Characteristics & Number (\%) \\
\hline \multicolumn{2}{|l|}{ Relative Characteristics } \\
\hline $\begin{array}{l}\text { Gender } \\
\text { Female } \\
\text { Male }\end{array}$ & $\begin{array}{l}107(50.2) \\
106(49.8)\end{array}$ \\
\hline $\begin{array}{l}\text { Age } \\
\begin{array}{l} \\
18-29 \\
30-39 \\
40-49 \\
50-59 \\
60+\end{array}\end{array}$ & $\begin{array}{l}29(13.6) \\
42(19.7) \\
57(26.8) \\
55(25.8) \\
30(14.1)\end{array}$ \\
\hline $\begin{array}{l}\text { Level of Education } \\
\text { Primary (5 year) } \\
\text { Secondary(8 year) } \\
\text { High School (12 year) } \\
\text { University + }\end{array}$ & $\begin{array}{r}15(7.0) \\
39(18.3) \\
67(31.5) \\
92(43.2)\end{array}$ \\
\hline $\begin{array}{l}\text { Relation with Patient } \\
\text { Child } \\
\text { Spouse } \\
\text { Parent } \\
\text { Sibling } \\
\text { Second-degree relative }\end{array}$ & $\begin{array}{r}125(58.7) \\
28(13.1) \\
18(8.5) \\
18(8.5) \\
24(11.3)\end{array}$ \\
\hline
\end{tabular}

\section{Patient Characteristics}

\begin{tabular}{|l|r|}
\hline $\begin{array}{l}\text { Gender } \\
\text { Female } \\
\text { Male }\end{array}$ & $84(39.4)$ \\
Age & $129(60.6)$ \\
\hline $18-34$ & $24(11.3)$ \\
$35-49$ & $18(8.5)$ \\
$50-64$ & $41(19.2)$ \\
$65-79$ & $86(40.4)$ \\
$80+$ & $44(20.7)$ \\
\hline Disease Diagnosis & \\
Chronic obstructive pulmonary disease & $76(35.7)$ \\
Post-op care & $40(18.8)$ \\
Polytrauma & $30(14.1)$ \\
Cerebrovascular disease & $28(13.1)$ \\
Cardiovascular disease & $13(6.1)$ \\
Others & $26(12.2)$ \\
\hline
\end{tabular}

3 
Table 2 (on next page)

Table 2

Comparision of The Mean Item Scores of Patient Relatives and Nurses 
1

2 Table 2. Comparision of The Mean Item Scores of Patient Relatives and Nurses

3

\begin{tabular}{|c|c|c|c|c|}
\hline Dimensions & Items & $\begin{array}{l}\text { Relatives } \\
\text { (Rank) } \\
\text { Mean } \pm \text { SD }\end{array}$ & $\begin{array}{l}\text { Nurse } \\
\text { (Rank) } \\
\text { Mean } \pm \text { SD }\end{array}$ & $\mathbf{p}$ \\
\hline Asurance/Proxymity & $\begin{array}{l}\text { To be assured the best care possible is } \\
\text { being given to the patient }\end{array}$ & (1) $3.93 \pm 0.26$ & (1) $3.69 \pm 0.46$ & $<0.001$ \\
\hline Information & $\begin{array}{l}\text { To be called at home about changes in the } \\
\text { patient's condition }\end{array}$ & (2) $3.93 \pm 0.26$ & $(12) 3.35 \pm 0.68$ & 0.000 \\
\hline Asurance/Proxymity & $\begin{array}{l}\text { To be assured it is alright to leave the } \\
\text { hospital for a while }\end{array}$ & (3) $3.93 \pm 0.28$ & (3) $3.52 \pm 0.50$ & $<0.001$ \\
\hline Asurance/Proxymity & $\begin{array}{l}\text { To feel that the hospital personnel care } \\
\text { about the patient }\end{array}$ & (4) $3.91 \pm 0.29$ & (6) $3.47 \pm 0.58$ & $<0.001$ \\
\hline Asurance/Proxymity & $\begin{array}{l}\text { To know specific facts concerning the } \\
\text { patient's progress }\end{array}$ & (5) $3.89 \pm 0.32$ & (8) $3.46 \pm 0.50$ & $<0.001$ \\
\hline Information & $\begin{array}{l}\text { To know exactly what is being done for the } \\
\text { patient }\end{array}$ & (6) $3.86 \pm 0.36$ & (4) $3.48 \pm 0.57$ & $<0.001$ \\
\hline Asurance/Proxymity & To have questions answered honestly & (7) $3.84 \pm 0.39$ & (2) $3.55 \pm 0.54$ & $<0.001$ \\
\hline Asurance/Proxymity & To feel there is hope & (8) $3.83 \pm 0.37$ & (13) $3.34 \pm 0.58$ & $<0.001$ \\
\hline Information & $\begin{array}{l}\text { To know how the patient is being treated } \\
\text { medically }\end{array}$ & (9) $3.83 \pm 0.41$ & $(11) 3.35 \pm 0.56$ & $<0.001$ \\
\hline Information & To know why things were done for patient & (10) $3.83 \pm 0.41$ & (14) $3.34 \pm 0.65$ & $<0.001$ \\
\hline Support/Comfort & To feel accepted by the hospital staff & (11) $3.80 \pm 0.44$ & (5) $3.48 \pm 0.60$ & 0.001 \\
\hline Asurance/Proxymity & $\begin{array}{l}\text { To receive information about the patient at } \\
\text { least once a day }\end{array}$ & (12) $3.80 \pm 0.45$ & (25) $3.00 \pm 0.75$ & $<0.001$ \\
\hline Information & $\begin{array}{l}\text { To be told about transfer plans while they are } \\
\text { being made }\end{array}$ & (13) $3.80 \pm 0.45$ & (22) $3.17 \pm 0.65$ & $<0.001$ \\
\hline Information & $\begin{array}{l}\text { To know about types of staff members taking } \\
\text { care of the patient }\end{array}$ & (14) $3.76 \pm 0.46$ & (16) $3.31 \pm 0.72$ & $<0.001$ \\
\hline Asurance/Proxymity & To talk to the doctor every day & (15) $3.75 \pm 0.46$ & (20) $3.20 \pm 0.71$ & $<0.001$ \\
\hline Information & $\begin{array}{l}\text { To have a specific person to call at the } \\
\text { hospital when unable to visit }\end{array}$ & (16) $3.75 \pm 0.54$ & (27) $2.96 \pm 0.87$ & $<0.001$ \\
\hline Asurance/Proxymity & $\begin{array}{l}\text { To know which staff members could give } \\
\text { what type of information }\end{array}$ & (17) $3.71 \pm 0.48$ & (9) $3.46 \pm 0.57$ & 0.005 \\
\hline Information & $\begin{array}{l}\text { To talk about the possibility of the patient's } \\
\text { death }\end{array}$ & (18) $3.55 \pm 0.59$ & (17) $3.30 \pm 0.54$ & 0.005 \\
\hline Support/Comfort & $\begin{array}{l}\text { To be told about other people that could help } \\
\text { with problems }\end{array}$ & $(19) 3.55 \pm 0.63$ & (21) $3.17 \pm 0.55$ & $<0.001$ \\
\hline Asurance/Proxymity & To have directions as to what to do at the & (20) $3.52 \pm 0.59$ & (15) $3.33 \pm 0.78$ & 0.111 \\
\hline
\end{tabular}




\begin{tabular}{|c|c|c|c|c|}
\hline & bedside & & & \\
\hline Asurance/Proxymity & $\begin{array}{l}\text { To have explanations of the environment } \\
\text { before going into the critical care unit for the } \\
\text { first time }\end{array}$ & (21) $3.52 \pm 0.69$ & (7) $3.47 \pm 0.69$ & 0.671 \\
\hline Support/Comfort & To see the patient frequently & (22) $3.50 \pm 0.71$ & (36) $2.70 \pm 0.96$ & $<0.001$ \\
\hline Information & To have visiting hours started on time & (23) $3.45 \pm 0.59$ & (18) $3.30 \pm 0.60$ & 0.087 \\
\hline Support/Comfort & $\begin{array}{l}\text { To talk about feelings about what has } \\
\text { happened }\end{array}$ & (24) $3.41 \pm 0.73$ & (10) $3.36 \pm 0.56$ & 0.544 \\
\hline Support/ Comfort & To have friends nearby for support & (25) $3.34 \pm 0.68$ & (19) $3.28 \pm 0.59$ & 0.553 \\
\hline Support/Comfort & To talk to the same nurse every day & (26) $3.21 \pm 0.73$ & (39) $2.37 \pm 0.94$ & $<0.001$ \\
\hline Support/Comfort & $\begin{array}{l}\text { To have another person with you visiting the } \\
\text { critical care unit }\end{array}$ & (27) $3.21 \pm 0.84$ & (29) $2.91 \pm 0.68$ & 0.007 \\
\hline Support/Comfort & To visit at any time & (28) $3.17 \pm 0.82$ & (40) $2.35 \pm 1.01$ & $<0.001$ \\
\hline Support/Comfort & To have a bathroom near the waiting room & (29) $3.13 \pm 0.85$ & (23) $3.04 \pm 0.69$ & 0.421 \\
\hline Support/Comfort & To help with the patient's physical care & (30) $2.99 \pm 0.84$ & (38) $2.65 \pm 0.91$ & 0.016 \\
\hline Support/Comfort & $\begin{array}{l}\text { To have comfortable furniture in the waiting } \\
\text { room }\end{array}$ & (31) $2.92 \pm 0.97$ & (30) $2.87 \pm 0.95$ & 0.738 \\
\hline Support/Comfort & To feel it is all right to cry & (32) $2.88 \pm 0.88$ & (26) $2.98 \pm 0.69$ & 0.369 \\
\hline Support/Comfort & To have good food available in the hospital & (33) $2.86 \pm 0.96$ & (24) $3.02 \pm 0.86$ & 0.279 \\
\hline Support/Comfort & To have a telephone near the waiting room & (34) $2.83 \pm 1.01$ & (33) $2.81 \pm 0.99$ & 0.920 \\
\hline Support/Comfort & $\begin{array}{l}\text { To be told about someone to help with family } \\
\text { problems }\end{array}$ & 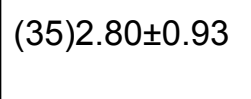 & (31) $2.83 \pm 0.75$ & 0.758 \\
\hline Support/Comfort & $\begin{array}{l}\text { To have someone be concerned about with } \\
\text { your health }\end{array}$ & (36) $2.78 \pm 0.94$ & (28) $2.94 \pm 0.71$ & 0.168 \\
\hline Support/Comfort & $\begin{array}{l}\text { To have a place to be alone while in the } \\
\text { hospital }\end{array}$ & (37) $2.78 \pm 0.96$ & (35) $2.74 \pm 0.83$ & 0.793 \\
\hline Support/Comfort & To be alone at any time & (38) $2.53 \pm 0.85$ & (34) $2.80 \pm 0.81$ & 0.038 \\
\hline Support/Comfort & To have a pastor visit & (39) $2.37 \pm 1.01$ & (37) $2.65 \pm 0.89$ & 0.066 \\
\hline Support/Comfort & To be told about chaplain services & (40) $2.35 \pm 1.02$ & (32) $2.81 \pm 0.85$ & 0.001 \\
\hline
\end{tabular}




\section{Table 3(on next page)}

Table 3

Comparision of Mean Subscale Dimension Scores of Patient Relatives and Nurses 
1 Table 3. Comparision of Mean Subscale Dimension Scores of Patient Relatives and 2 Nurses

3

4

5

6

7

8

9
10

11

12

13

14

15

16

17

18

19

20

21 